\title{
Impact of Abandoned Structures on Residents in Ilorin, Kwara State, Nigeria
}

\author{
ADIGUN F. O, *ABOLADE O, IGE J.O, ADEOSUN A. O, OLADELE J.A \\ Department of Urban and Regional Planning, Faculty of Environmental Sciences \\ Ladoke Akintola University of Technology, PMB 4000, Ogbomoso, Oyo State Nigeria \\ *Corresponding Author
}

\begin{abstract}
The increasing incidence of abandoned structures coupled with the associated seemly insurmountable environmental, psychosocial and economic risks in a developing country like Nigeria is a nerve racking problem of concern to the government and the communities. The study therefore, within the context of the three residential densities the study examined the incidence, causes and impacts of abandoned structures with a view to providing information on the extents and effects of abandoned structures on residents in Ilorin. The study utilized primary data obtained with the aid of questionnaire from 428 residents collected in the ratio 3:2:1 in high, medium and low density residential areas. Four indices were developed: 'Environmental Impact of Abandonment' (EIAI), 'Psycho-Social Impact of Abandoned Structures' (PSIASI), 'Economic Impact of Abandonment' (EcIAI) and 'Suggested Solutions to Abandonment' (SSA). It is observed that the incidence of abandoned structures varies significantly among the residential neighbourhoods of Ilorin metropolis $(\mathrm{F}=9.458$ and $\mathrm{p}=0.036$ at $95 \%$ confidence level). The magnitude of the six categories of abandonment in Ilorin metropolis is more in the high density area then in medium and low density. Residents of different residential densities of Ilorin do not have the same or similar views about the environmental effect of abandonment in their areas $(\mathrm{F}=$ 4.604 and $p=0.0160$. The study recommends as suggested by respondents increase in basic salary $(\mathrm{SSA}=, 4.31)$ local planning authority should work on blight control $(\mathrm{SSA}=4.29)$ and there should be proper site selection before commencement of building projects $(\mathrm{SSA}=.4 .28)$.
\end{abstract}

DOI: $10.7176 /$ RHSS/9-18-08

Publication date:September $30^{\text {th }} 2019$

\section{Introduction}

Abandonment of landed property is a global issue and abounds everywhere; both in the developed and developing countries (Hoe, 2013). Abandoned structures are worldwide common plight of alarming impacts and has been subject of considerable research studies (Accordino and Johnson, 2000; Kohler and Hassler, 2002; Mallach, 2006; Nefs, 2006; Han, 2014). The consequential effects of such structures are obvious on the economy, residents and environment as a whole. Abandonment has been observed as an indicator of real estate market failure, symptom of urban disinvestment and the product of urban shrinking (Gospodini, 2012).

Abandoned landed property has been viewed as image of uninhabited structure or building in a grave ruin, possibly boarded up with trash, and cramped with vandalism (Cohen 2001). Abandonment; a practical symbol of wastage occurs when a developer decides to discontinue temporarily or permanently a project under development (Cohen, 2001, Ewusi-Mensah and Przasnyski, 1991). Spelman, (1993) defined abandonment as unilateral transfer of ownership; non-destructive means of getting rid of one's ownership of property.

In contemporary time, problems posed by abandonment are seemingly evident and marked regional differences with enormous environmental impacts that soak deep into physical, health, socio-economic and cultural norms of the environment (Akindele 2013. Mallach (2006) established that abandonment contributes to increasing danger of public health, safety, building collapse and incidence of fire disaster. Similarly, Skogan, and Spelman, (1993) reported that crime rate in term of drug use and prostitution is in relation with abandoned landed properties. Abandonment contributed to property value decline, arson and other crimes (Goetz, 1998; Bruhns, 2000; Shlay and Whitman, 2006; Adedibu and Akindele, 2007; Han, 2014). Consequently, Mallach, (2004) noted that the effects of crime on abandon landed property ravished communities for centuries coupled with the fact that crime is more prevalent in poor inner city neighborhoods than areas with more affluent. According to Akindele (2013), abandon structures provides meeting places where offenders who perpetrate crimes elsewhere can gather meet and plan their activities. Stolen goods are also temporarily kept in abandoned structures (Mallach 2004, Akindele 2013)

Nigerian cities are characterized with abandoned structures due to net result of inconsistent government policies, corruption, obsolete infrastructures, community interference, inadequate planning among others (Franks, 2006; Efenudu, 2010; Ikpefan, 2010). The situation in Ilorin; the study area is no exception. Abandoned landed properties in Ilorin city downgrade quality of life, create unattractive urban environment for the citizens, visitors as well as future investors. This contradicts the fundamental preoccupation of planning to make the city safe, healthy, beautiful and sustainable Keeble, (1969), Nenno, (1996) cited in Akindele, (2013). Pearsall and Lucas (2014) opined that abandoned property can be recognized as both a problem and an 
opportunity for planners and non-governmental organizations (NGOs) seeking to address community social and land use concerns. Therefore, to achieve the purpose of planning in any built up environment, prevalence of abandoned landed properties and their environmental impacts on the aesthetics and the general livability of towns and cities must be examined.

\section{The Study Area}

Ilorin is located in the transitional zone between the savannah zones and as a gateway linking the Northern Nigeria with the Southern part of Nigeria. It is the administrative seat of Kwara State Government. It is located on latitude $8^{0} 30^{\prime}$ North of the equator and longitude $4^{0} 34^{\prime}$ East of the Greenwich meridian. The region consists of three Local Government areas, which are Ilorin East, Ilorin West and Ilorin South local governments with their headquarters at Oke-Oyi, Oja - Oba and Fufu respectively. Its population is 777,667 (NPC, 2006). Over the years, the city has grown spatially and there has been influxes of people which were necessitated by spontaneous development as well as corresponding increase in commercial and industrial activities. This abandonment have diverse effects on residents' in Ilorin. Figure 1 and Figure 2 illustrates the study area and its delineation.

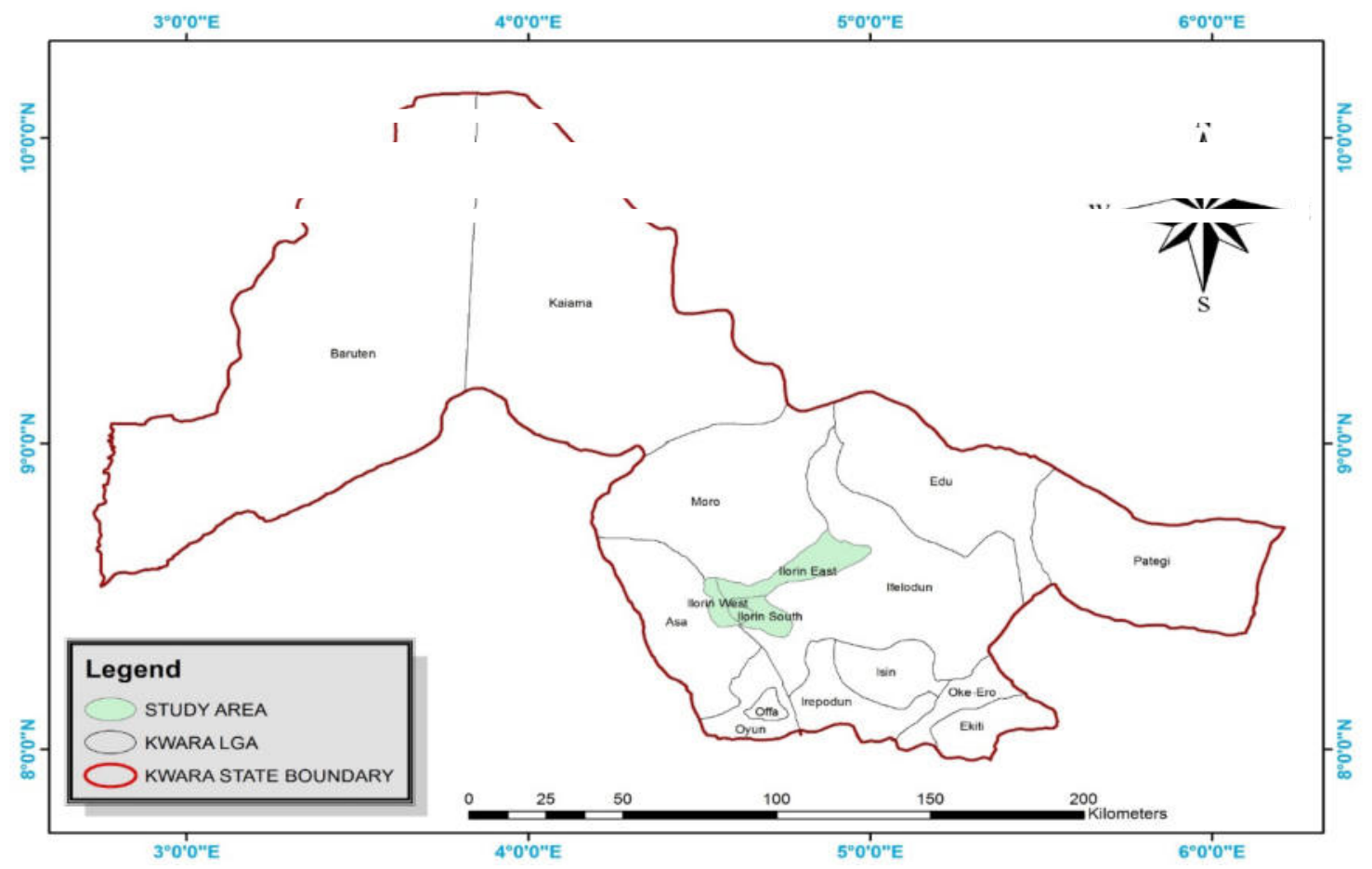

Figure 1: Study Area within the Context of Kwara State Source: Kwara State Ministry of Housing and Urban Development, 2012

Figure 1.1: Kwara State within the National Context 


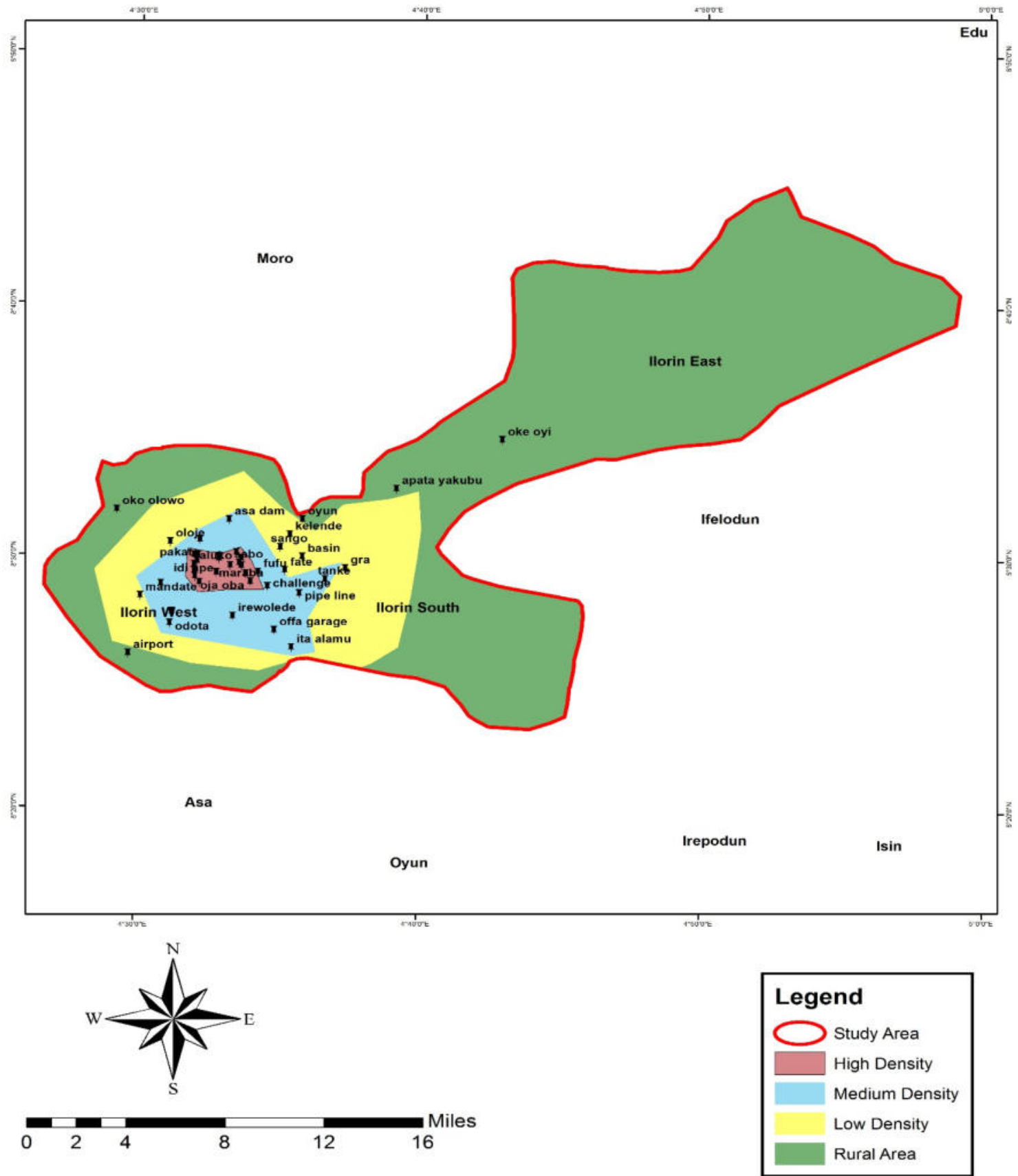

Figure 2 : Study Area Delineation

Source: Authors Field Survey and Google Earth, 2015

\section{CHAPTER TWO}

\section{Research Methods}

This study utilizes primary and secondary data from primary and secondary sources. Primary data was obtained directly from the field through reconnaissance survey, direct observations and measurement which involved the physical counting of abandoned buildings and copies of structured questionnaire were administered on residents in the study area. In addition to this, secondary information from published materials such as imagery of Ilorin was obtained via Google Earth. Maps were also obtained from Physical Planning Authority in Ilorin. These were 
used to complement the primary data. The multi-stage sampling techniques were adopted. Ilorin comprises of three local government areas which are Ilorin East, Ilorin West and Ilorin South. Urban neighbourhoods in these Local Government areas were used for this study. Further clarification in identifying localities within the urban areas of Ilorin was extracted from Thomas (2013). Stratified sampling technique was used to segregate urban neighbourhood in the study area into three (3) strata, which are high, medium and low density residential respectively. From the identified localities, random sampling was used to select 6, 4, and 2 localities in the high, medium and low density of urban neighbourhood at the ratio of 3:2:1. (Adeboyejo and Onyeonoru, 2003) These constitute the sample frame. Population of buildings in each locality was documented via Google Earth and field survey. Total building population observed in the sampled localities in urban area of Ilorin was 4265. From this $0.1 \%$ of the building population was taken as the sample size. Four hundred and twenty eight questionnaires were distributed in the study. Physical counting of abandoned structures was done in the study area.

The $\mathrm{Z}$ scores of the counted abandoned structures were calculated to determine the relative significance of each category of abandonment in the area. Four indices termed 'Environmental Impact of Abandonment' (EIAI), 'Psycho-Social Impact of Abandoned Structures' (PSIASI), Economic Impact of Abandonment (EcIAI) and Suggested Solutions to Abandonment were developed. With the use of Likhert scale, impacts of abandoned structures were measured via, very high very low in the study area and it was thus rated as: very high (5); high (4); moderate (3); low (2) and very low (1). Fourteen, ten and three variables were used the environmental, psycho-social and economic impacts of abandonment on residents of Ilorin while seven variables were used rate the suggested solution to abandonment in the study area. SSA was measured via, on a Likhert scale of five as: Strongly Agreed (5); Agreed (4); Indifferent (3); Disagreed (2) and Strongly Disagreed (1). ANOVA was used to test the intra urban variation in the causes and impacts of abandoned structures.

\section{Discussion of Results}

4.1 Incidence of Abandoned Structures

Table 1: Residents' Awareness of Abandoned Structures in their Areas

\begin{tabular}{|c|c|c|c|c|}
\hline \multirow{2}{*}{$\begin{array}{l}\text { Awareness } \\
\text { abandonment }\end{array}$} & \multicolumn{4}{|c|}{ Residential Area } \\
\hline & High (\%) & Medium (\%) & Low (\%) & Total (\%) \\
\hline Yes & 49.8 & 29.4 & 14.7 & 93.9 \\
\hline No & 3.3 & 1.2 & 1.6 & 6.1 \\
\hline Total & 53.1 & 30.6 & 16.3 & 100 \\
\hline
\end{tabular}

Source: Author's Field Survey, 2015

Documented in Table 1 is the respondents' awareness of incidence of abandoned structures in the study area. Within Ilorin metropolis, majority of respondents acknowledged the presence of abandoned structures in high $(49.8 \%)$, medium $(29.4 \%)$ and low $(14.7 \%)$ residential densities while only few noted otherwise in high $(3.3 \%)$, medium $(1.2 \%)$ and in low $(1.6 \%)$ densities respectively. With these, it can therefore be deduced that the incidence of abandoned structures is almost found everywhere across the residential densities of Ilorin. There is no significant intra-urban variation in residents' awareness of incidence of abandonment in the study area $\left(\mathrm{X}^{2}=1.63, \mathrm{df}=2, \mathrm{p}=0.442\right)$.

Table 2: Residents' Reported Number of Abandoned Structures in their Areas

\begin{tabular}{|lllll|} 
Number of Abandoned & Residential Area & & & \\
& High (\%) & Medium (\%) & Low (\%) & Total (\%) \\
\hline $\mathbf{1 - 3}$ & 27.9 & 15.7 & 15.7 & 59.4 \\
\hline $\mathbf{4 - 6}$ & 22.7 & 14.8 & 0 & 37.6 \\
\hline $\mathbf{7 - 9}$ & 1.7 & 0 & 0 & 1.7 \\
\hline $\mathbf{1 0}-\mathbf{1 2}$ & 0.4 & 0.9 & 0 & 1.3 \\
\hline Total & 52.8 & 31.4 & 15.7 & 100 \\
\hline
\end{tabular}

Source: Author's Field Survey, 2015

Table 2 indicated the number of abandoned structures in the study area as reported by the respondents. In Ilorin, significant proportion of respondents (59.4\%) observed that $1-3$ buildings were abandoned in their area. Next to this is $4-6$ abandoned buildings with $37.6 \%$. Only proportion of $1.7 \%$ and $1.3 \%$ reported that $7-9$ buildings and 10-12 buildings respectively were abandoned in their area. It can therefore be deduced that there is high incidence of abandoned structures in the study area as noted by residents (Table 1) and as equally observed by past authors such as Setterfield, (1997); Cohen, (2001); Mallach, (2004); Adedibu and Akindele, (2007) in their various research work. In high residential area of Ilorin, significant proportion of respondents $(27.9 \%)$ observed that 1-3 buildings were abandoned. Next to this category are $4-6$ abandoned buildings with $22.7 \%$ and $7-9$ abandoned structures with $1.7 \%$. The observed pattern is similar in medium and low density areas where bulk of respondents reported that $1-3$ buildings were abandoned in their areas with $15.7 \%$ each. This shows that there is high incidence of abandonment in the study area. The result of Chi-square on spatial variation 
in the number of abandoned structures among three residential densities of Ilorin implies that there is significant difference in the number of abandoned structures among the three residential areas $\left(X^{2}=33.626, d f=6, p=\right.$ $0.000)$.

\subsection{1: Physical Counting of Abandoned Building among Residential Area}

Table 3 indicated the $\mathrm{z}$-score result in urban area. Among the residential densities, there is high incidence of dilapidated abandoned structures ZA with positive values in Oja-oba (0.30943), Saw mill (0.52365), Itamerin (0.09521), Ajikobi (0.30943), which are predominantly high density residential area. These may be due to the fact that high density area are regarded as the core area of the city where development began and buildings in these area have served considerable number of generations coupled with poor maintenance culture. In medium density area there is occurrence of uncompleted abandoned structures ZB with positive values in Olunlade (2.30884) and Odota (2.30884) (see plate 1 and 2). In low density, the category of abandoned structure found is majorly sound and completed abandoned structures ZC in GRA (1.42345) and LES (2.74874). This may be due to the fact that low density area are inhabited by high income earners and affluent group, in which they build and even go on vacation for couples of year, leaving such structures abandoned. In some cases where they have rented out such structures, if not properly maintained by the tenant; they prefer leaving the structures unoccupied than letting it out.

Table 3: Physical Counting of Abandoned Building among Residential Area

\begin{tabular}{|c|c|c|c|c|c|c|c|c|c|c|c|c|c|}
\hline \multirow[t]{2}{*}{ Urban area } & \multirow{2}{*}{$\begin{array}{l}\text { Sampled } \\
\text { localities }\end{array}$} & \multicolumn{12}{|c|}{ Category of Abandoned Building } \\
\hline & & $\mathbf{A}$ & B & $\mathbf{C}$ & D & $\mathbf{E}$ & $\mathbf{T}$ & $\mathbf{Z A}$ & ZB & $\mathbf{Z C}$ & ZD & $\mathbf{Z E}$ & ZT \\
\hline \multirow{6}{*}{$\begin{array}{l}\text { High } \\
\text { Density } \\
\text { Residential }\end{array}$} & Oja-Oba & 8 & 2 & 0 & 1 & 8 & 23 & 0.30943 & -0.55731 & -0.78535 & -1.02627 & 0.67924 & 0.18379 \\
\hline & Saw mill & 9 & 3 & 1 & 0 & 9 & 22 & 0.52365 & -0.07962 & -0.34359 & -1.40327 & 0.96357 & 0.06972 \\
\hline & Ita merin & 7 & 0 & 0 & 5 & 6 & 18 & 0.09521 & -1.51269 & -0.78535 & 0.48172 & 0.11057 & -0.38660 \\
\hline & Pakata & 5 & 2 & 0 & 5 & 3 & 15 & -0.33323 & -0.55731 & -0.78535 & 0.48172 & -0.74243 & -0.72884 \\
\hline & Ajikobi & 8 & 1 & 1 & 3 & 7 & 20 & 0.30943 & -1.03500 & -0.34359 & -0.27228 & 0.39491 & -0.15844 \\
\hline & Maraba & 2 & 2 & 1 & 4 & 6 & 15 & -0.97590 & -0.55731 & -0.34359 & 0.10472 & 0.11057 & -0.71844 \\
\hline \multirow{4}{*}{$\begin{array}{l}\text { Medium } \\
\text { Density } \\
\text { Residential }\end{array}$} & Tanke & 2 & 3 & 5 & 2 & 3 & 15 & -0.97590 & -0.07962 & 1.42345 & -0.64927 & -0.74243 & -0.71844 \\
\hline & Pipeline & 3 & 3 & 4 & 2 & 4 & 16 & -0.76168 & -0.07962 & 0.98169 & -0.64927 & -0.45809 & -0.61476 \\
\hline & Olunlade & 1 & 8 & 0 & 2 & 0 & 11 & -1.19012 & 2.30884 & -0.78535 & -0.64927 & -1.59543 & -1.18516 \\
\hline & Odota & 4 & 8 & 1 & 3 & 3 & 19 & -0.54745 & 2.30884 & -0.34359 & -0.27228 & 0.74243 & -0.27252 \\
\hline \multirow{2}{*}{$\begin{array}{l}\text { Low } \\
\text { Density } \\
\text { Residential }\end{array}$} & GRA & 0 & 3 & 5 & 1 & 0 & 9 & -1.40434 & -0.07962 & 1.42345 & -1.02627 & -1.59543 & -1.41332 \\
\hline & LES & 0 & 4 & 8 & 0 & 1 & 13 & -1.40434 & 0.39808 & 2.74874 & -1.40327 & -1.31109 & -0.95700 \\
\hline Total & & 49 & 39 & 26 & 28 & 50 & 216 & & & & & & \\
\hline
\end{tabular}

Source: Author's Field Survey, 2015

$\mathrm{A}=$ Dilapidated Abandoned Buildings and $\mathrm{ZA}=\mathrm{Z}$-score of Dilapidated Abandoned Buildings.

$\mathrm{B}=$ Uncompleted Abandoned Buildings and $\mathrm{ZB}=\mathrm{Z}$-score of Uncompleted Abandoned Buildings.

$\mathrm{C}=$ Sound and Completed Abandoned Buildings and $\mathrm{ZC}=\mathrm{Z}$-score of Sound and Completed Abandoned Buildings.

$\mathrm{D}=$ Uncompleted and Dilapidated Abandoned Buildings and ZD $=$ Z-score of Uncompleted and Dilapidated Abandoned Buildings.

$\mathrm{E}=$ Old but Unoccupied Abandoned Buildings and ZE $=\mathrm{Z}$-score of Old but Unoccupied Abandoned Buildings. $\mathrm{T}=$ Total Number of Abandoned Buildings in sampled locality and ZT $=$ Z-score of Total Number of Abandoned Buildings.

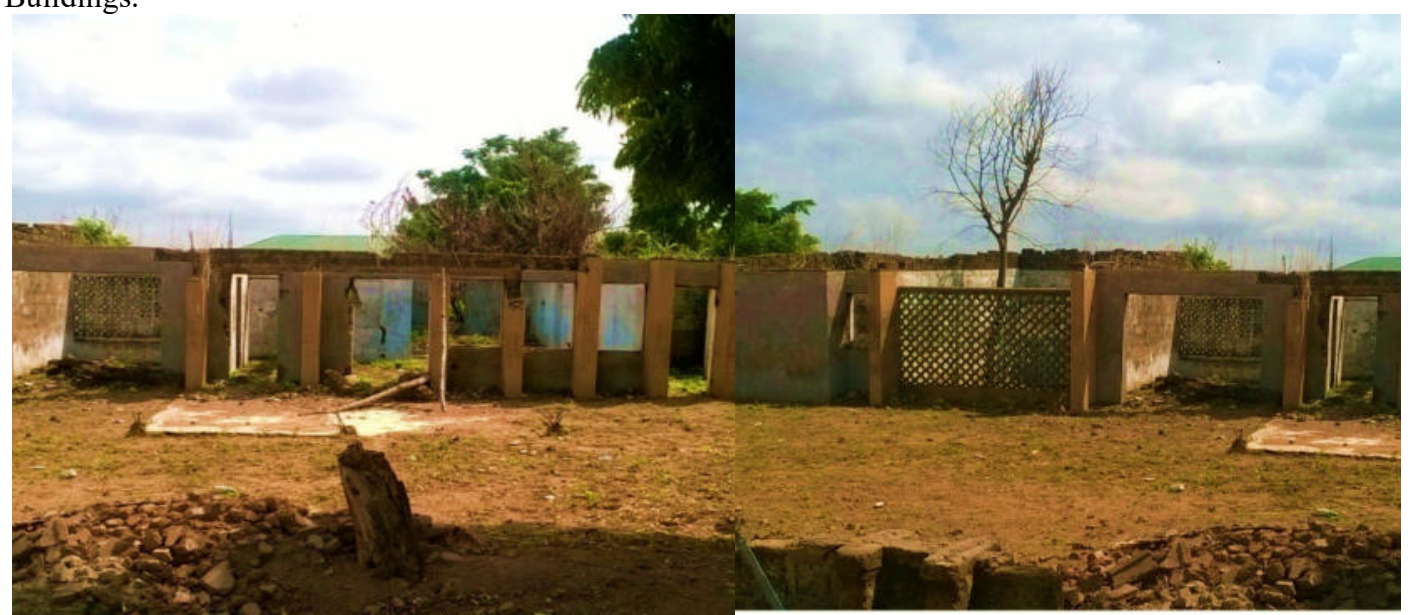

Plate 1: Uncompleted and Dilapidated Abandoned Structures in the Odota.

Source: Author's Field Survey, 2015 


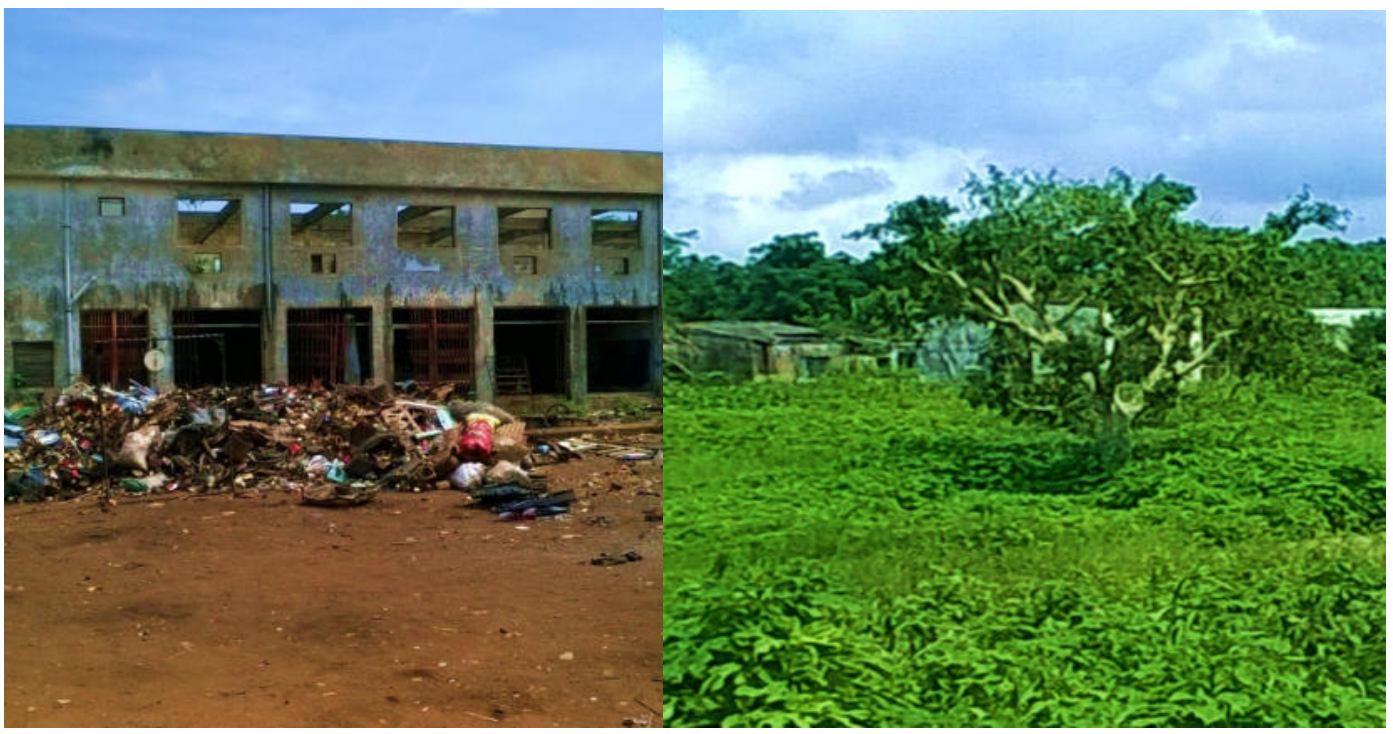

Plate 2: Uncompleted Abandoned Structure Turn into Refuse Dumps in Tanke Area.

Source: Author's Field Survey, 2015

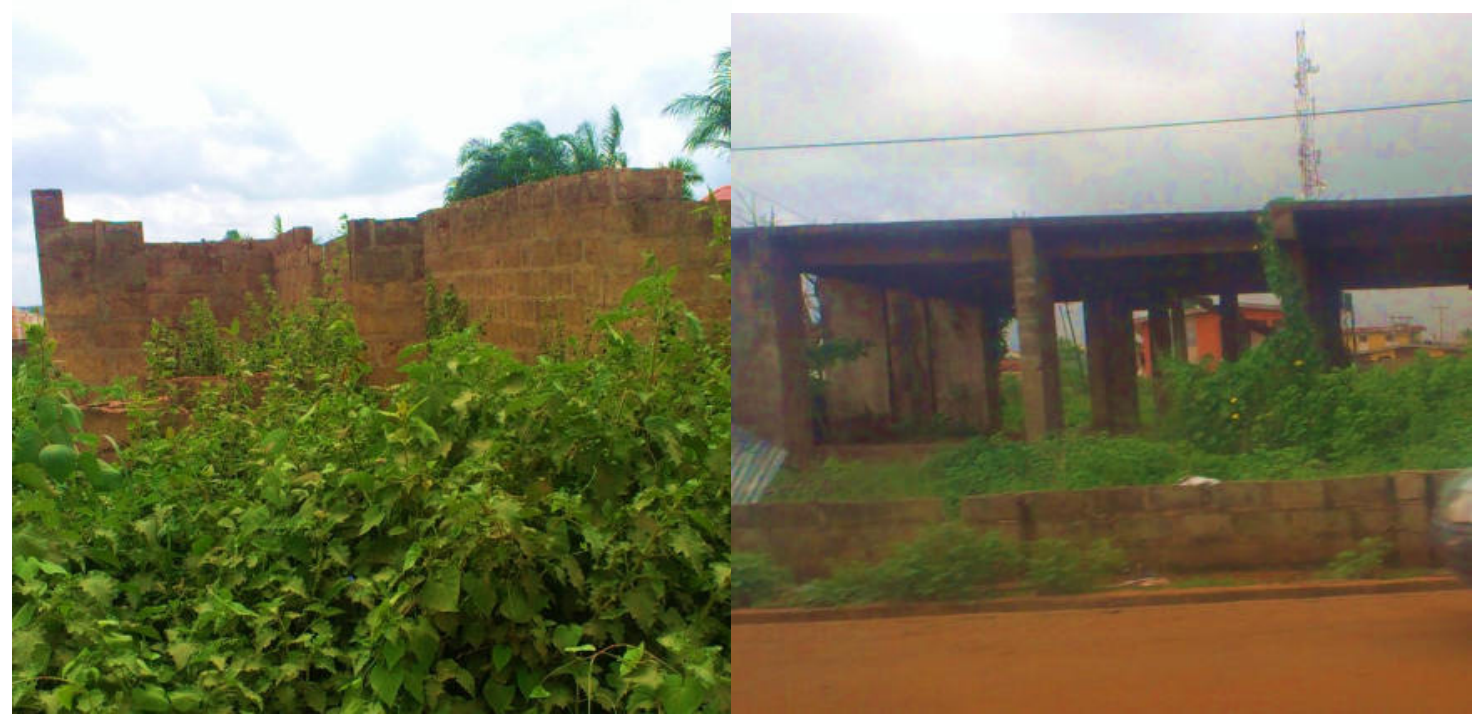

Plate 3: Uncompleted and Bushy Abandoned Structures in Maraba Area.

Source: Author's Field Survey, 2015

Table 4: Result of ANOVA on Intra-Urban Variation in the Incidence of Abandonment in Ilorin Metropolis using the Counted Data

\begin{tabular}{llllll|} 
Source of Variation & Sum of square & df & Mean square & F & Sig. \\
Between Groups & 35.303 & 1 & 1.858 & 17.088 & 0.000 \\
Within Groups & 33.055 & 195 & 0.109 & & \\
Total & 68.358 & 196 & & & \\
\hline
\end{tabular}

Source: Author's Field Survey, 2015

Within Ilorin metropolis, the result of ANOVA established the variation in the incidence of abandoned structures among the residential neighbourhoods of Ilorin (Table 4). It is observed that the incidence of abandoned structures varies significantly among the residential neighbourhoods of Ilorin metropolis i.e. residents of different residential densities of Ilorin metropolis do not have the same or similar views about the incidence of abandonment in their area with $(\mathrm{F}=9.458$ and $\mathrm{p}=0.036$ at $95 \%$ confidence level). This implies that there is significant variation in the presence of abandoned structures among the residential densities of Ilorin metropolis. It can however be inferred that categories of abandoned structures is not the same across the residential neighborhoods of Ilorin metropolis. 


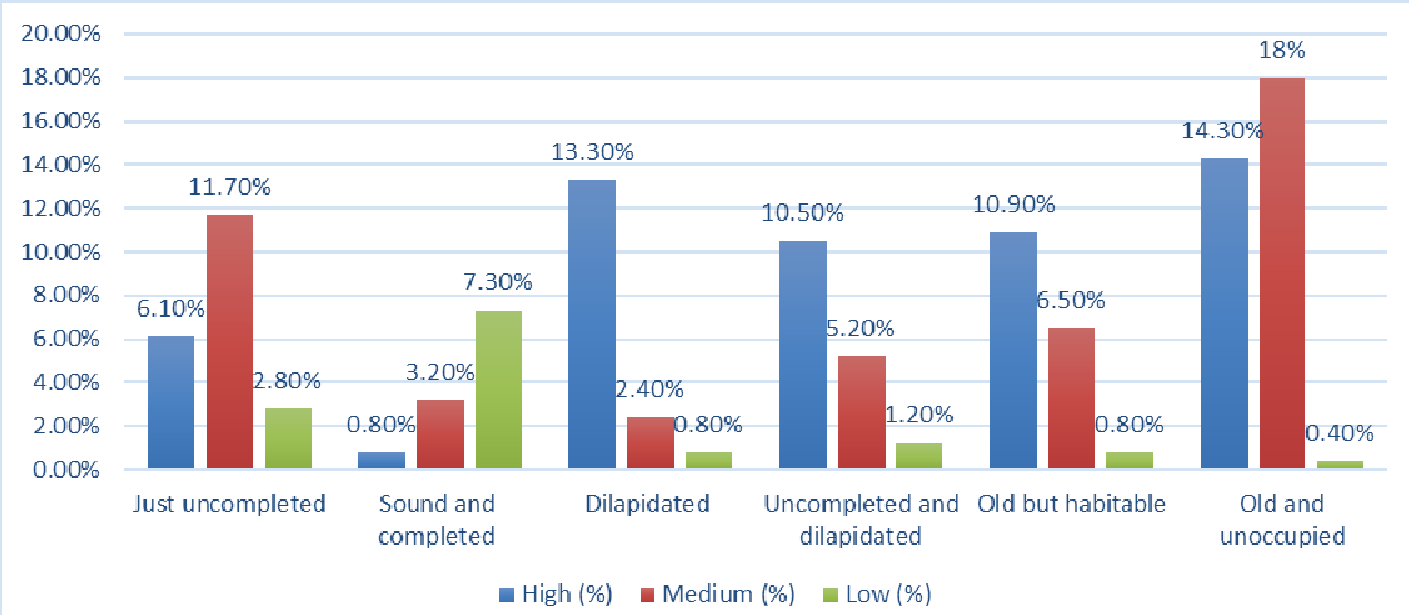

Figure 3:Intra-Urban Variation in the Prevalence of Abandoned Structures across Residential Densities Source: Authors Fieldwork (2015)

The magnitude of the six categories of abandonment in Ilorin metropolis is more in the high density area then in medium and low density as detailed in Figure 3. The highest occurring categories of abandoned structures in the high density is 'dilapidated abandoned buildings' (13.3\%), 'old but habitable abandoned buildings' (10.9\%) and 'old but unoccupied abandoned building $(10.6 \%)$, this is probably because the sampled localities are core areas of the study area therefore dilapidated, deteriorated and old abandoned buildings is common in the area. The highest occurring categories of abandoned structures in low density area is 'sound and completed abandoned buildings' (7.3\%) followed by 'uncompleted abandoned buildings' (2.8\%). This is probably because they are financially buoyant to build structures without being occupied by any one. Also, they may go for vacation for couple of years leaving the structures unoccupied. In the medium density, the highest occurring categories of abandoned structures are 'uncompleted abandoned buildings' (11.7\%) followed by 'old but habitable abandoned buildings' with $6.5 \%$. This may be associated to current global economic crisis in the world. This notwithstanding, the relative incidence of each category of abandoned structure among the residential area differs.

\section{2: Intra-Urban Variations in Causes of Abandoned Structures in Study Area}

The study used ANOVA tool to establish the result of statistical variation. Some of the causes of abandoned structures are lack of fund/financial constraint, dilapidation, disaster, migration, death of owners among several others. The result is presented in Table 5. The result revealed that residents of different residential densities of Ilorin do have the same or similar views about the causes of abandonment in their areas. The probability value suggests that there are no significant differences in the perceived causes of abandonment among residential areas of Ilorin metropolis at $95 \%$ confidence level. The causes of abandonment concerned include death of building owners, dilapidation, lack of fund, litigation, extended family conflict, government policy, spiritualism, disaster, robbery and discomfort. This result indicated that residents have similar beliefs about what actually cause abandonment in their areas. 


\begin{tabular}{|c|c|c|c|c|c|c|c|}
\hline $\begin{array}{l}\text { Causes of } \\
\text { Abandonment }\end{array}$ & $\begin{array}{l}\text { Sources of } \\
\text { Variation }\end{array}$ & $\begin{array}{l}\text { Sum of } \\
\text { Squares }\end{array}$ & df & $\begin{array}{l}\text { Mean } \\
\text { Square }\end{array}$ & $\mathrm{F}$ & Sig. & Remark \\
\hline \multirow[t]{3}{*}{ Death of .Owner } & $\begin{array}{l}\text { Between } \\
\text { Groups }\end{array}$ & .151 & 2 & .076 & .203 & .816 & \multirow[t]{3}{*}{ Insignificant } \\
\hline & Within Groups & 84.614 & 327 & .373 & & & \\
\hline & Total & 84.765 & 329 & & & & \\
\hline \multirow[t]{3}{*}{ Dilapidation } & $\begin{array}{l}\text { Between } \\
\text { Groups }\end{array}$ & .657 & 2 & .329 & .601 & .549 & \multirow[t]{3}{*}{ Insignificant } \\
\hline & Within Groups & 124.165 & 327 & .547 & & & \\
\hline & Total & 124.822 & 329 & & & & \\
\hline \multirow[t]{3}{*}{ Lack of Fund } & $\begin{array}{l}\text { Between } \\
\text { Groups }\end{array}$ & .118 & 2 & .059 & .140 & .869 & \multirow[t]{3}{*}{ Insignificant } \\
\hline & Within Groups & 95.725 & 327 & .422 & & & \\
\hline & Total & 95.843 & 329 & & & & \\
\hline \multirow[t]{3}{*}{ Litigation } & $\begin{array}{l}\text { Between } \\
\text { Groups }\end{array}$ & .282 & 2 & .141 & .160 & .002 & \multirow[t]{3}{*}{ Significant } \\
\hline & Within Groups & 195.900 & 323 & .878 & & & \\
\hline & Total & 196.181 & 325 & & & & \\
\hline \multirow{3}{*}{$\begin{array}{l}\text { Extended Family } \\
\text { do not Agree on } \\
\text { Use }\end{array}$} & $\begin{array}{l}\text { Between } \\
\text { Groups }\end{array}$ & .023 & 2 & .012 & .019 & .001 & \multirow[t]{3}{*}{ Significant } \\
\hline & Within Groups & 136.972 & 327 & .603 & & & \\
\hline & Total & 136.996 & 329 & & & & \\
\hline \multirow[t]{3}{*}{$\begin{array}{l}\text { Government } \\
\text { Policy }\end{array}$} & $\begin{array}{l}\text { Between } \\
\text { Groups }\end{array}$ & .647 & 2 & .323 & .417 & .000 & \multirow[t]{3}{*}{ Significant } \\
\hline & Within Groups & 176.001 & 327 & .775 & & & \\
\hline & Total & 176.648 & 329 & & & & \\
\hline \multirow[t]{3}{*}{ Spiritualism } & $\begin{array}{l}\text { Between } \\
\text { Groups }\end{array}$ & .705 & 2 & .352 & .380 & .684 & \multirow[t]{3}{*}{$\begin{array}{c}\text { Not } \\
\text { Significant }\end{array}$} \\
\hline & Within Groups & 210.256 & 327 & .926 & & & \\
\hline & Total & 210.961 & 329 & & & & \\
\hline \multirow[t]{3}{*}{ Natural Disaster } & $\begin{array}{l}\text { Between } \\
\text { Groups }\end{array}$ & .051 & 2 & .026 & .034 & .967 & \multirow[t]{3}{*}{$\begin{array}{c}\text { Not } \\
\text { Significant }\end{array}$} \\
\hline & Within Groups & 170.823 & 327 & .753 & & & \\
\hline & Total & 170.874 & 329 & & & & \\
\hline \multirow[t]{3}{*}{ Robbery } & $\begin{array}{l}\text { Between } \\
\text { Groups }\end{array}$ & .218 & 2 & .109 & .155 & .006 & \multirow[t]{3}{*}{ Significant } \\
\hline & Within Groups & 159.612 & 327 & .703 & & & \\
\hline & Total & 159.830 & 329 & & & & \\
\hline \multirow[t]{3}{*}{ Migration } & $\begin{array}{l}\text { Between } \\
\text { Groups }\end{array}$ & .281 & 2 & .140 & .229 & .005 & \multirow[t]{3}{*}{ Significant } \\
\hline & Within Groups & 139.041 & 327 & .613 & & & \\
\hline & Total & 139.322 & 329 & & & & \\
\hline \multirow[t]{3}{*}{ Discomfort } & $\begin{array}{l}\text { Between } \\
\text { Groups }\end{array}$ & .991 & 2 & .496 & .719 & .000 & \multirow[t]{3}{*}{ Significant } \\
\hline & Within Groups & 156.491 & 327 & .689 & & & \\
\hline & Total & 157.483 & 329 & & & & \\
\hline
\end{tabular}

\section{Source: Author's Field Survey, 2015}

\subsection{Impacts of Abandoned Structures on Resident's}

Every individual is bond to experience or respond to external stimuli whether palatable or not. The impact of abandonment experienced may be environmental, social, psychological and even economical. In the same vein, residents experience various impacts of abandonment at different degrees. In this study, the impacts that were examined include the psycho-social impact of abandonment and the variables used to measure it include theft, rape, stress, fear of robbery, staying in door, avoid walking at night, afraid of building collapse, poor aesthetic 
look, ghost zone among several others. The environmental impact of abandonment include criminals' hideout, criminals' meeting center, smokers' site, vagrants' settlement, defecation venue, reptiles' lodge, temporal store of stolen good, lunatics' residence, pollution, arson, refuse dump site, odours and smell from refuse dump, disfigure neighbourhood landscape among several others. The economic impacts of abandonment assessed include property vandalization, property value decline and communal development levy decline among several others. Three indices were developed to measure the impacts of abandonment in the study area. Environmental Impact of Abandonment Index (EIAI) was employed to rate environmental impact experiences that are associated with the incidence of abandonment in Ilorin. Psycho-Social Impact of Abandoned Structures Index (PSIASI) was used in measuring the psycho-social effect of abandonment on residents in the study area. Economic impact of abandonment index (EcIAI) was used in measuring the economic effect of abandonment on residents in Ilorin.

\subsection{1: Environmental Impacts of Abandonment Experienced in Ilorin metropolis.}

Fourteen variables were used in determining the level of environmental impact observed as a result of incidence of abandoned structures in the study area. The extent of EIAI variables associated with incidence of abandonment was measured among the three residential densities of Ilorin metropolis. The mean EIAI for the whole study area and each of the residential areas was computed. For each residential density, the mean of EIAI was calculated and compared with EIAI of each abandonment variable for the whole Ilorin metropolis. The EIAI variables were differentiated into two groups. First are variables with positive deviation that is above the mean EIAI value while the second group includes those with negative deviation that is below the mean EIAI value. This implies that residents perceived more of EIAI variable with positive deviation than EIAI variable with negative deviation.

In the Ilorin metropolis, the mean EIAI value for the three residential areas is 3.60 (Table 6.). The high density has the high mean EIAI value $(\mathrm{EIAI}=3.69)$ compared to medium density $(\mathrm{EIAI}=3.55)$ then the low density with the lowest mean EIAI value (EIAI = 3.54). On the aggregate level, environmental impact of abandonment highly experienced by residents include 'smoker site' (EIAI = 3.97), 'disfigure neighbourhood landscape'(EIAI = 3.92), 'fueling of bush burning' (EIAI = 3.73)'defecation venue and refuse dumpsites' each with EIAI value of 3.70, 'arson' (EIAI = 3.61) and 'vagrant settlement' (EIAI = 3.55). The environmental impact that residents perceived less include 'lunatic residence' $(\mathrm{EIAI}=3.40)$, 'pollution' $(\mathrm{EIAI}=3.42)$, 'temporal store for stolen goods' (EIAI = 3.44), 'criminals hideout' and criminals meeting center each with EIAI value of 3.45, and 'reptiles lodge' (EIAI = 3.49). It can therefore be inferred that the more the incidence of abandoned structures, the more its environmental effects perceived by residents across the density residential area. Within the high density neighbourhood, environmental impact of abandonment variables that has much effects on residents (above the mean EIAI value of Ilorin metropolis) include 'fueling of bush burning' (EIAI $=4.33$ ), 'arson' (EIAI = 4.27) 'disfiguration of neighbourhood landscape' (EIAI = 4.05), 'smoker site' (EIAI = 4.03), 'refuse dumpsite and defecation venue' each with EIAI value of 3.86, 'odour/smell from waste dump' (EIAI = 3.69) and 'reptile lodge' (EIAI = 3.61). Observed environmental impacts of abandonment that residents experienced less include 'lunatic residence' (EIAI = 3.42), 'criminal hideout' (EIAI = 3.43), 'criminal meeting center' (EIAI = 3.44) and 'temporal store for stolen goods' and 'pollution' each with EIAI value of 3.45, 'vagrant settlement' (EIAI = 3.59). It can therefore be inferred that the EIAI impacts perceived by residents in high density area include 'fueling of bush burning' while the least is 'lunatic residence'. Virtually all environmental variables are perceived more in high density than other residential densities probably because the area sampled are regarded as core areas of the cities and building are clustered together and there is poor aesthetic of the environment, smokers then have their place in available dilapidated abandoned buildings for smoking. Defecation in abandoned buildings is pronounced in high density due to the fact that most buildings in such area lack toilet facilities. The alternative available is 'shot-put' in abandoned structures probably because the abandoned structures have no specific guardian. Also, because of the squalid environment characterized by high density area featuring uncontrolled/unmanaged waste water channels, inadequate drainage facilities, dangerous reptiles such as snake and scorpion have a place in the core areas than other residential areas.

In the medium density, environmental impacts of abandonment that residents experienced more include 'disfiguration of neighbourhood landscape' (EIAI = 4.06); 'smokers site' (4.01) 'refuse dump on abandoned building' $($ EIAI $=3.64)$, 'defecation venue' $(E I A I=3.63)$, 'vagrant settlement' $(\mathrm{EIAI}=3.57)$. Observed environmental impacts of abandonment that residents experienced less in medium density include 'Arson' (EIAI = 3.30), 'lunatic residence' (EIAI = 3.39), 'odours/smells from waste' $($ EIAI = 3.43); 'pollution' $($ EIAI = 3.44) 'criminals meeting center' and 'temporal store of stolen goods' (EIAI $=3.44)$ each. It can therefore be inferred that the most and least EIAI impacts perceived by residents in medium density area include 'disfiguration of neighbourhood landscape' and 'arson' respectively. Environmental impact variables that medium density dwellers perceived more than other residential densities include disfiguration of neighbourhood landscape as a result of their level of education and presence of abandoned structures. Criminal hideout and criminal meeting centers have a higher index value in medium than other residential density probably because the dweller goes to 
work early and daily making the environment less crowded, thereby making the environment favorable for criminals such as thief to plan, carry out operation as well as kept stolen goods temporarily in abandoned buildings before evacuating such goods.

Table 7: Environmental Impact of Abandoned Structures (EIAI) in Ilorin metropolis.

\begin{tabular}{|c|c|c|c|c|c|c|}
\hline \multirow[t]{2}{*}{ Variables } & \multicolumn{3}{|c|}{ EIAI for Density residential } & \multirow[t]{2}{*}{ EIAI } & \multirow{2}{*}{$\begin{array}{l}\text { EIAI } \\
* \text { EIAI }\end{array}$} & \multirow{2}{*}{$\begin{array}{l}(\text { EIAI } \\
\text { *EIAI }^{2}\end{array}$} \\
\hline & High & Medium & Low & & & \\
\hline Smokers Site & 4.03 & 4.01 & 3.86 & 3.97 & 0.46 & 0.2116 \\
\hline $\begin{array}{l}\text { Disfigure Neighbourhood } \\
\text { Landscape }\end{array}$ & 4.05 & 4.06 & 3.64 & 3.92 & 0.41 & 0.1681 \\
\hline Fueling of bush burning & 4.33 & 3.47 & 3.40 & 3.73 & 0.22 & 0.0484 \\
\hline Defecation Venue & 3.86 & 3.63 & 3.62 & 3.70 & 0.19 & 0.0361 \\
\hline Refuse Dump Site & 3.86 & 3.64 & 3.62 & 3.70 & 0.19 & 0.0361 \\
\hline Arson & 4.27 & 3.30 & 3.26 & 3.61 & 0.10 & 0.0100 \\
\hline Vagrant Settlement & 3.59 & 3.57 & 3.50 & 3.55 & 0.04 & 0.0016 \\
\hline Odour/Smell from Waste & 3.69 & 3.43 & 3.39 & 3.50 & -0.01 & 0.0001 \\
\hline Reptiles Lodge & 3.61 & 3.46 & 3.39 & 3.49 & -0.02 & 0.0004 \\
\hline Criminals Hideout & 3.43 & 3.49 & 3.42 & 3.45 & -0.06 & 0.0036 \\
\hline $\begin{array}{l}\text { Criminals meeting } \\
\text { Center }\end{array}$ & 3.44 & 3.46 & 3.44 & 3.45 & -0.06 & 0.0036 \\
\hline $\begin{array}{l}\text { Temporal store for stolen } \\
\text { goods }\end{array}$ & 3.45 & 3.46 & 3.42 & 3.44 & -0.07 & 0.0049 \\
\hline Pollution & 3.45 & 3.44 & 3.36 & 3.42 & -0.09 & 0.0081 \\
\hline Lunatic Residence & 3.42 & 3.39 & 3.38 & 3.40 & -0.11 & 0.0121 \\
\hline TOTAL & 49.58 & 49.73 & 51.68 & 50.33 & & \\
\hline *EIAI & 3.69 & 3.55 & 3.54 & 3.60 & & \\
\hline
\end{tabular}

Source: Author's Field Survey, 2015

In the low density area, impacts of abandonment that residents experienced that is above the average value of EIAI include 'smokers site' (EIAI = 3.86), 'disfiguration of neighbourhood landscape' (EIAI = 3.64), refuse dump in abandoned building and defecation venue' (EIAI = 3.62) each, 'vagrant settlement' (EIAI = 3.50). The environmental impacts that residents experienced less in low density include, 'arson' (EIAI = 3.26), 'pollution' $(E I A I=3.36)$,'lunatic residence'(EIAI $=3.38)$, 'odour/smell from waste' and 'reptiles lodge' $(E I A I=3.39)$.It can therefore be deduced that the most and least EIAI impacts perceived by residents in low density area include 'smokers' site' and 'arson'. In low density area, virtually all the environmental effect variables are perceived less in their neighbourhood probably because all facilities are put in place such as refuse collection center, availability of toilet facilities and proper landscape of the neighbourhood.

It was observed that some environmental impacts of abandonment variables experienced among the three residential areas have EIAI value either above or below the mean EIAI of Ilorin metropolis. On a general note, it therefore be concluded that the more the incidence of abandoned structures, the more its environmental effects perceived by residents across the density residential areas.

4.3.2: Intra-Urban variation on Environmental Impacts of Abandonment Observed/Experienced in the Study Area.

This section attempts to establish the intra-urban variations in the environmental impacts of abandoned structures in the study area by employing ANOVA tool. Some of the environmental impacts include pollution, vagrant settlement, refuse dump, criminals' hideout among several others. The result is presented in Table 8 .

The ANOVA result revealed that residents of different residential densities of Ilorin do not have the same or similar views about the environmental effect of abandonment in their areas. The probability value suggests that there is significant differences in the environmental effect of abandonment among residential areas of Ilorin metropolis at $95 \%$ confidence level with $\mathrm{F}=4.604$ and $\mathrm{P}=0.016$. The effects of abandonment concerned include arson, refuse dump, vagrant settlement and fueling of bush burning. This result indicated that residents have similar observation about the effects of abandonment in their residential areas.

As a matter of fact, it was observed that variables used in measuring environmental effect do not have statistical significant variations at $\mathrm{p}<0.05$ confidence level as earlier noted. However, it can be observed from reconnaissance survey carried out in the study area and it can therefore be rightly said that there are variations intuitively in the environmental effect variables across the area. This intuitive variation may however be due to chance 
Table 8: Intra- Urban Variation in Environmental Impacts of Abandoned Structures in Ilorin Metropolis.

\begin{tabular}{|l|r|r|r|r|r|}
\hline & \multicolumn{1}{|c|}{ Sum of } & & & \\
& Squares & df & Mean Square & F & Sig. \\
\hline Between Groups & .539 & 2 & .270 & 4.604 & .016 \\
Within Groups & 2.284 & 39 & .059 & & \\
Total & 2.823 & 41 & & & \\
\hline
\end{tabular}

Source: Author's Field Survey, 2015

\subsection{3: Psycho-Social Impacts of Abandoned Structure Index (PSIASI)}

In measuring Psycho-Social Impact of Abandoned Structures Index PSIASI, ten variables associated with the incidence of abandonment were rated by respondents. The extent of the ten (psycho-social) variables associated with incidence of abandonment was measured between urban and rural area of Ilorin and among the three residential densities of Ilorin metropolis. The PSIASI mean for the study area was computed and compared with abandonment PSIASI value for the two areas. For each density residential, the mean of PSIASI was calculated and compared with PSIASI of each abandonment variable for the whole of Ilorin metropolis. The psycho-social impact variables were differentiated into two groups. First are variables with positive deviation above the mean PSIASI value while the second group includes those with negative deviation below the mean PSIASI value. This implies that residents experienced more effect of PSIASI variable with positive deviation than PSIASI variable with negative deviation.

\subsection{4: Psycho-social Impact of Abandonment in Ilorin Metropolis}

This section however, documents the psycho-social effects of abandonment among the three residential densities. The mean PSIASI value for Ilorin metropolis is 3.78 a value greater than the mean PSIASI of the high density (3.68),compared to PSIASI value of low density (3.78) and medium density (3.80) (see Table 9). In Ilorin metropolis, the psycho-social effects of abandonment highly felt by residents in respect of include 'theft' (PSIASI $=4.43)$; ' poor aesthetic look of environment' (PSIASI $=4.22)$, 'fear of robbery' (PSIASI $=4.08)$, and 'rape' (PSIASI = 3.83). Psycho-social variables of which residents experienced less include 'drug abuse' (PSIASI = 3.27); 'ghost zone' (PSIASI = 3.37); 'fear of building collapse' (PSIASI = 3.53); ' avoid walking at night' and 'stress' (PSIASI = 3.63) each; 'staying indoor' (PSIASI = 3.72).It can therefore be concluded that the most and least psycho-social effects perceived by residents in Ilorin metropolis include 'theft' and 'drug abuse'.

In the high density, some of the psycho-social effect variables considered to have high impacts on the residents. This include 'poor aesthetic look of environment' (PSIASI = 4.47); 'theft' (PSIASI = 4.32); 'avoid walking at night' (PSIASI = 3.77); 'staying indoor' (PSIASI = 3.72); 'rape' (PSIASI = 3.71). The psycho-social effects that residents experienced less in the high density include 'ghost zone' (PSIASI = 3.39), 'drug abuse' (PSIASI = 3.49), 'stress' (PSIASI = 3.57) and 'fear of building collapse' (PSIASI = 3.64). This implies that the incidence of abandoned structures is evident in poor aesthetic look of the environment in high density area and ghost zone is least in high density probably because they have a compact or dense environment and development. It can therefore be inferred that the most and least psycho-social effects perceived by residents in high density area include 'poor aesthetic look' and 'ghost zone'.

In the medium density, some variables have high effects on residents' average of level for all the variables. These include 'theft' (PSIASI = 4.35); 'poor aesthetic look of environment' (PSIASI = 4.42); 'fear of robbery' $($ PSIASI $=3.99)$ and 'rape' (PSIASI = 3.74). The psycho-social variables of which residents experienced less in medium density include 'ghost zone '(PSIASI = 3.39), 'drug abuse' (PSIASI = 3.48); 'stress' (PSIASI = $3.57)$; 'fear of building collapse'(PSIASI $=3.65)$; 'avoid walking at night' and 'staying in door' (PSIASI = 3.72) each. This implies that presence of abandoned buildings connote poor aesthetic look of the environment in medium density probably because of their level of education and exposure. It can therefore be inferred that the most and least psycho-social effects perceived by residents in medium density area include 'poor aesthetic look' and 'ghost zone'.

In the low density, some variables have high effects on residents' average of level for all the variables. These include 'fear of robbery' (PSIASI $=4.56)$, 'theft' (PSIASI $=4.44)$; 'rape' (PSIASI $=4.03$ ), 'poor aesthetic look' (PSIASI = 3.76) and 'stress' (PSIASI = 3.75). The psycho-social variables of which residents experienced less in low density include drug abuse' (PSIASI $=2.89$ ), afraid of building collapse (PSIASI $=3.31$ ), 'ghost zone'(PSIASI = 3.32) and 'staying in door' (PSIASI = 3.36).It can therefore be deduced that the most and least psycho-social effects perceived by residents in low density area include 'fear of robbery' and 'drug abuse'.

On a general note, considering the variables index value across the densities, it can be deduced that low density dwellers perceived more act of theft than other densities probably because the thieves focus more on the affluent groups than others. As a result to this they are vulnerable to 'fear of robbery' in the low density than other densities. Also, low density have a higher index value of 'rape' than other residential area probably because of the nature of their environment, that it is usually fenced up and mind your business. As a result of this even if the victims cry for help, it is possible that no one respond in low density residential area. Reverse is the 
case in high density, the victims can easily be rescued due to the nature of their compact nature of their environment because it is highly populated as well as availability of most residents in front of their house.

Table 9: Psycho-social Impact of Abandoned Structures (PSIASI) in Ilorin Metropolis.

\begin{tabular}{|c|c|c|c|c|c|c|}
\hline \multirow[t]{2}{*}{ Variables } & \multicolumn{3}{|c|}{ PSIASI For Density residential } & \multirow[t]{2}{*}{ PSIASI } & \multirow{2}{*}{$\begin{array}{l}\text { PSIASI } \\
* \text { PSIASI }\end{array}$} & \multirow{2}{*}{$\begin{array}{l}(\text { PSIASI } \\
{ }^{*} \text { PSIASI) }\end{array}$} \\
\hline & High & Medium & Low & & & \\
\hline Theft & 4.32 & 4.35 & 4.44 & 4.43 & 0.66 & 0.4356 \\
\hline Fear of Robbery & 3.70 & 3.99 & 4.56 & 4.08 & 0.39 & 0.1521 \\
\hline Poor Aesthetic Look & 4.47 & 4.42 & 3.76 & 4.22 & 0.30 & 0.0900 \\
\hline Rape & 3.71 & 3.74 & 4.03 & 3.83 & 0.14 & 0.0196 \\
\hline Stress & 3.57 & 3.57 & 3.75 & 3.63 & -0.06 & 0.0036 \\
\hline Staying In Door & 3.72 & 3.72 & 3.36 & 3.72 & -0.09 & 0.0081 \\
\hline $\begin{array}{l}\text { Avoid Walking at } \\
\text { Night }\end{array}$ & 3.77 & 3.72 & 3.36 & 3.63 & -0.13 & 0.0169 \\
\hline $\begin{array}{l}\text { Fear Of Building } \\
\text { Collapse }\end{array}$ & 3.64 & 3.65 & 3.31 & 3.53 & 0.16 & 0.0256 \\
\hline Ghost Zone & 3.39 & 3.39 & 3.32 & 3.37 & -0.32 & 0.1024 \\
\hline Drug Abuse & 3.49 & 3.48 & 2.89 & 3.27 & -0.67 & 0.4489 \\
\hline Total & 36.80 & 38.03 & 37.78 & 37.73 & & \\
\hline *PSIASI & 3.68 & 3.80 & 3.78 & 3.78 & & \\
\hline
\end{tabular}

Source: Author's Field Survey, 2015

This implies that the pattern observed for the whole urban area is similar as explained earlier. High mean value of PSIASI in the medium and low densities attests to the fact that residents experience some psycho-social effect variables more than the remaining densities. This may be due to their level of exposure and education attained. Psycho-social effects of incidence of abandonment in urban area increase from the medium density to the low density and the high density areas.

4.3.5: Intra-Urban variation on Psycho-social Impacts of Abandonment Observed/Experienced in the Study Area.

This section attempts to establish the intra-urban variations in the psycho-social impacts of abandoned structures in the study area. The study therefore uses ANOVA tools to establish the result if there is intra - urban variation in the impacts perceived by respondents in the study area. Some of the psycho-social impacts include theft, rape, fear of robbery, drug abuse, ghost zone among several others. The results is presented in Table 10 .

Similar pattern is observed (Table 10) in the intra-urban variation in the psycho-social effect of abandoned structures among the residential densities of Ilorin metropolis using one way ANOVA. The ANOVA result revealed that residents of different residential densities of Ilorin do have the same or similar views about the psycho-social effect of abandonment in their areas. The probability value suggests that there are significant differences in the psycho-social effect of abandonment among residential areas of Ilorin metropolis at $95 \%$ confidence level with $\mathrm{F}=0.249$ and $\mathrm{P}=0.782$. The effects of abandonment concerned include theft, rape, afraid of building collapse among several others. This result indicated that residents have similar observation about the effects of abandonment in their residential areas.

As a matter of fact, it was observed that psycho-social effect variables do not have statistical significant variations at $\mathrm{p}<0.05$ confidence level as earlier noted. However, it can be rightly said that there are variations intuitively in the environmental effect variables across the area. This intuitive variation may however be due to chance.

Table 10: Intra- Urban Variation in Psycho-social Impacts of Abandoned Structures in in Ilorin Metropolis.

\begin{tabular}{|l|r|r|r|r|r|}
\hline & \multicolumn{1}{|c|}{ Sum of Squares } & \multicolumn{1}{c|}{ Df } & \multicolumn{1}{c|}{ Mean Square } & F & Sig. \\
\hline Between Groups & .088 & 2 & .044 & .249 & .782 \\
Within Groups & 4.749 & 27 & .176 & & \\
Total & 4.836 & 29 & & & \\
\hline
\end{tabular}

Source: Author's Field Survey, 2015

4.3.6: Economic Impact of Abandonment Index (EcIAI)

For Economic Impact of Abandoned Structures Index EcIAI, three variables associated with the incidence of abandonment were rated by respondents. The extent of effect of the three (economic) variables associated with incidence of abandonment were measured among the three residential densities of Ilorin metropolis. For each residential density, the mean of EcIAI was calculated and compared with EcIAI of each abandonment variable for the whole urban area. Variables of economic impact of abandonment were differentiated into two groups. First are variables with positive deviation above the mean EcIAI value while the second group includes those 
with negative deviation below the mean EcIAI value. This implies that residents experienced more economic effect of abandonment variable with positive deviation than EcIAI variable with negative deviation.

\subsection{7: Economic Impact of Abandonment (EcIAI) in Ilorin Metropolis}

The previous section provided a comparison of economic effect of likelihood of occurrence of abandonment between the two areas of the study area. This section however documents the intra-urban variation in the economic effect of abandonment among the three residential densities. The mean EcIAI value for Ilorin metropolis is 3.68 , a value less than the mean EcIAI of the low density (EcIAI $=3.72$ ) and medium density $($ EcIAI $=3.69)$, but greater than the mean EcIAI in high density (EcIAI =3.62) (Table 11). In Ilorin metropolis, economic effects of abandonment that residents experienced more include 'affecting communal development' $($ EcIAI $=3.81)$ and 'property value decline' $($ EcIAI $=3.61)$. The economic variables of which residents' experienced less include 'property vandalization' (EcIAI $=3.60)$. It can therefore be concluded that the most and least economic effects perceived by residents in Ilorin metropolis include 'affecting communal development levy' and 'property vandalization'. On a general note, abandoned structures have economic effects on residents either to increase the communal development levy of every available dwellers or decrease the communal development income tag to a specific project within the neighbourhood. In high density areas, residents experienced less economic impact than average of level for the metropolis except 'affecting communal development levy' (EcIAI =3.79). The economic variables of which residents experienced less include 'property vandalization' (EcIAI = 3.49) and 'property value decline' (EcIAI =3.59). It can therefore be deduced that the most and least economic effects perceived by residents in high density area include 'affecting communal development levy' and 'property vandalization'.

In the medium density, residents experienced more economic impact than average of level for the metropolis. 'Affecting communal development levy' $(\mathrm{EcIAI}=4.01)$ is considered to the greatest in the medium density area. The economic variables of which residents experienced less include 'property vandalization' $(\mathrm{EcIAI}=3.50)$ and 'property value decline' (EcIAI $=3.58)$. It can therefore be deduced that the most and least economic effects perceived by residents in medium density area include 'affecting communal development levy' and 'property vandalization'.

Table 11: Economic Impact of Abandoned Structures (EcIAI) in Ilorin metropolis.

\begin{tabular}{|c|c|c|c|c|c|c|}
\hline \multirow[t]{2}{*}{ Variables } & \multicolumn{3}{|c|}{ EcIAI for Density Residential } & \multirow[t]{2}{*}{ EcIAI } & \multirow{2}{*}{$\begin{array}{l}\text { EcIAI } \\
{ }^{*} \text { EcIAI }\end{array}$} & \multirow{2}{*}{$\begin{array}{ll}- & (\text { EcIAI } \\
& * \text { EcIAI })^{2}\end{array}$} \\
\hline & High & Medium & Low & & & \\
\hline $\begin{array}{l}\text { Affect Communal Development } \\
\text { levy }\end{array}$ & 3.79 & 4.01 & 3.64 & 3.81 & 0.13 & 0.0169 \\
\hline Property Value Decline & 3.59 & 3.58 & 3.72 & 3.63 & 0.05 & 0.0025 \\
\hline Property Vandalization & 3.49 & 3.50 & 3.81 & 3.60 & 0.08 & 0.0064 \\
\hline Total & 10.87 & 11.09 & 11.17 & 11.04 & & \\
\hline *EcIAI & 3.62 & 3.69 & 3.72 & 3.68 & & \\
\hline
\end{tabular}

Source: Author's Field Survey, 2015

In the low density area, residents experienced more economic impact than average of level for the metropolis including 'property vandalization' ( $($ EcIAI $=3.81))$, 'property value decline' $(3.72)$. The economic variables of which residents experienced less include 'affecting communal development levy' (EcIAI =3.64). It can therefore be deduced that the most and least economic effects perceived by residents in low density area include 'property vandalization' and 'affecting communal development levy'. This implies that the pattern observed for Ilorin metropolis is similar as explained earlier. Higher EcIAI value in the low density attests to the fact that residents in low residential areas felt more economic effect of abandonment than other residential densities. This may be due to the fact that land value and rent in low density is high than other residential areas. For such structures to sit unused is a great loss instead such structures should be used to generate income or help others. Effects of incidence of abandonment in urban area increases from the low density to the medium to the high density areas.

Table 12: Intra-Urban Variation in Economic Impacts of Abandoned Structures in in Ilorin Metropolis.

\begin{tabular}{|l|r|r|r|r|r|}
\hline & Sum of Squares & Df & Mean Square & F & Sig. \\
\hline Between Groups & .016 & 2 & .008 & .228 & .803 \\
Within Groups & .212 & 6 & .035 & & \\
Total & .228 & 8 & & & \\
\hline
\end{tabular}

Source: Author's Field Survey, 2015

Similar pattern is observed (Table 12) in the intra-urban variation in the economic effect of abandoned structures among the residential densities of Ilorin metropolis using one way ANOVA. The ANOVA result revealed that residents of different residential densities of Ilorin do have the same or similar views about the economic effect of abandonment in their areas. The probability value suggests that there are no significant differences in the environmental effect of abandonment among residential areas of Ilorin metropolis at $95 \%$ 
confidence level. The effects of abandonment concerned include property vandalization and property value decline. This result indicated that residents have similar observation about the effects of abandonment in their residential areas. As a matter of fact, it was observed that economic effect variables do not have statistical significant variations at $\mathrm{p}<0.05$ confidence level as earlier noted. However, it can be rightly said that there are variations intuitively in the environmental effect variables across the area. This intuitive variation may however be due to chance.

\subsection{8: Intra - Urban Variation in the suggested solutions to Abandonment in Ilorin Metropolis}

In this section however, the intra-urban variation in level of agreement on possible suggestion on how to reduce the incidence of abandoned structures among the three residential densities is documented in (Table 13). The mean SSA value for Ilorin metropolis is 4.04, a value greater than the mean SSA of the low density $(\mathrm{SSA}=$ $3.82)$, but higher than SSA value of high density $(\mathrm{SSA}=4.14)$ and medium density $(\mathrm{SSA}=416)$. In Ilorin metropolis, the level of agreement to the possible suggestions made by respondents include 'increase in basic salary' (SSA = 4.31), 'local planning authority should be charged with blight control' (SSA = 4.29), 'proper consideration of site before commencement of building projects' (SSA $=4.28)$, 'maintenance culture should be enforced among citizens' (SSA = 4.21) and 'improvement in nation's economy' (SSA = 4.07). Suggestions with high level of disagreement among the urban dwellers include abandoned structures should be sold out (SSA = 3.37)and 'government should acquire all abandoned structures'(SSA = 3.77).Across the residential densities, similar pattern is observed in all densities except in low density area where charging of local planning authority to blight control has a greater index value, next to this is proper site selection before commencement of building projects with an index value of 4.08. Increase in basic salary has an index value of 3.81 in low density. It can be deduced that lack of fund is not the major issue of concern to incidence of abandoned structures in low density, probably because they are financially buoyant. That is why increase in basic salary do not have high index value in low density compared to other residential densities (see Table 13).

It can therefore be concluded that most of the residents in Ilorin metropolis strongly agreed that there should be increase in the basic salary, the local planning authority should also control blight as well as proper consideration of site before commencement of building project, enforcement of maintenance culture among citizens and general improvement in nation's economy. On a general note, it was observed that some of the sampled respondents have one abandoned structure or the other in some areas that is why the some respondent strongly disagreed that government should acquire abandoned structures in the study area.

Table 13: Intra- urban Variation of possible suggestion made by respondents in Ilorin metropolis.

\begin{tabular}{|c|c|c|c|c|c|c|}
\hline \multirow[t]{2}{*}{ Suggestions } & \multicolumn{4}{|c|}{$\begin{array}{l}\text { SSA for } \\
\text { Densities }\end{array}$} & \multirow[t]{2}{*}{$\begin{array}{l}\text { SSA } \\
* \text { SSA }\end{array}$} & \multirow[t]{2}{*}{$\begin{array}{l}(\mathrm{SSA} \\
* \mathrm{SSA})^{2}\end{array}$} \\
\hline & High & Medium & Low & & & \\
\hline Increase basic salary & 4.56 & 4.56 & 3.81 & 4.31 & 0.27 & 0.0729 \\
\hline $\begin{array}{l}\text { Local planning authority should be charged } \\
\text { to blight control }\end{array}$ & 4.26 & 4.28 & 4.33 & 4.29 & 0.25 & 0.0625 \\
\hline $\begin{array}{l}\text { Proper site selection should be considered } \\
\text { before commencement of building projects }\end{array}$ & 4.36 & 4.39 & 4.08 & 4.28 & 0.24 & 0.0576 \\
\hline $\begin{array}{l}\text { Maintenance culture should be enforced } \\
\text { among citizens }\end{array}$ & 4.46 & 4.44 & 3.72 & 4.21 & 0.17 & 0.0289 \\
\hline Improvement in nations economy & 4.30 & 4.26 & 3.64 & 4.07 & 0.03 & 0.0009 \\
\hline $\begin{array}{l}\text { Government should acquire all abandoned } \\
\text { structures }\end{array}$ & 3.81 & 3.81 & 3.69 & 3.77 & -0.27 & 0.729 \\
\hline Abandoned structures should be sold out & 3.26 & 3.40 & 3.44 & 3.37 & -0.67 & 0.4489 \\
\hline Total & 29.01 & 29.14 & 26.71 & 28.30 & & \\
\hline * SSA & 4.14 & 4.16 & 3.82 & 4.04 & & \\
\hline
\end{tabular}

Source: Author's Computation (2015)

\section{CONCLUSION}

The study has been able to establish that there is significant relationship between incidence of abandoned structures and residents' livability. It also established that there is significant variation in the incidence and causes of abandoned structures between urban and rural areas of Ilorin. The study has therefore made several recommendations which if strictly adhered to, the nation can record reduction in the incidence of abandoned structures thus enhancing the livability of residents in cities.

\section{RECOMMENDATIONS}

The observation of significant variation in spatial incidence of abandoned structures in this study indicated that areas (urban and rural) as well as density residential are not receiving the impact/effects of abandonment in the 
same degree. This therefore suggests the enforcement of periodic maintenance of structures among citizens.It is further recommended that there should be adequate access to wealth through improvement of nation's economy, increment in salary of government workers, establishment of community corporative societies supported by the federal government in provision of soft loan for low income earners with affordable interest and collateral. Adequate and proper site selection should be given due consideration before commencement of building projects by all developer. Government should enforce law that all planning provision relevant to development control becomes imperative in order to discourage urban dwellers from digging their graves at their door steps. Also, all abandoned property owners/relatives should be contacted periodically for bush clearance around the abandoned properties either by the landlord association or through their leader (bale or obas) and consistent visits to such sites should be encouraged among developers to avoid harboring of criminals, vagrant and the lunatics around such structures. Furthermore, it was recommended that some of the government owned abandoned structures should be lease out at a reduced cost. It can also be added that such abandoned structures can be auction or better still donated to the respective community for better usage.

\section{REFERENCES}

1. Accordino, J., Johnson, G.T., (2000): Addressing the Vacant and Abandoned Property Problem, Journal of Urban Affairs, 22(3), pp.301-315.

2. Adedibu, A. A. and Akindele, O. A. (2007): "The Significance of Landed Property Abandonment in Osogbo: A Planner"s perspective”. Journal of Nigerian Institute of Town Planners Vol XX No 1

3. Akindele O.A (2103): Environmental Effects of Abandoned Properties in Ogbomoso and Osogbo, Nigeria Ethiopian Journal of Environmental Studies and Management Vol.6 Supplement

4. Bruhns, H.R., (2000). Property taxation data for non-domestic buildings. Environment and Planning B: Planning and Design, 27(1), pp.33-49.

5. Cohen, J. (2001). "Abandoned Housing: Exploring Lessons from Baltimore." Housing Policy Debate 12(3): 415-448.

6. Efenudu (2010). An Assessment of the causes and effect of Abandonment and Development Projects on Real Property Values in Nigeria. Journal on Research in applied Natural and Social science. Vol. 2. 5.

7. Ewusi-Mensah, K. and Przasnyski, Z.H. (1991). On Information Systems Project Abandonment: An Exploratory Study of Organizational Practices. Management Information System Quarterly, 67-86.

8. Franks, T.R. (2006). Sustaining Projects Benefits: Masters Course Manual. University of Bradford, UK: Centre for International Development.

9. Goetz, E.G., Cooper, K., Thiele, B., Lam, H., (1998). Pay now or pay more later; St. Paul'es experience in rehabilitating vacant building. CURA Reporter, April issue, pp.12-15.

10. Gospodini, A. (2012), „Economic Crisis and the Shrinking Greek Cities ${ }^{\text {ee }}$, Proceedings of the 3rd Panhellenic Conference of DPRD, University of Thessaly, 27-30 September, Volos, Greece.

11. Han, H.S., (2014). The impact of abandoned properties on nearby property values. Housing Policy Debate, 24(2), p.311-334.

12. Hoe, Y.E. (2013). Causes of Abandoned Construction Projects in Malaysia. A Thesis report of M.Sc in Construction Management of the University Tunku, Abdul Rahman, Malaysia. Retrieved from googlescholar, October 2014

13. Ikpefan (2010). Project Financing: Causes and effects of Financing Abandoned Building Projects in Nigeria.

14. Keeble, L. (1969): Principles and Practice of Town and Country Planning. The Estate Gazette Limited 151 Wardour Street, London Wiv. 4bn.

15. Kohler, N., Hassler, U., 2002. The building stock as a research project. Building Research and Information, 30(4), p.226-236.

16. Mallach, A. (2004), Abandoned Properties: Effective Strategies to Reclaim Community Assets. Journal of Housing Facts and findings Vol 6 Issue 2

17. Mallach, A. (2006). Bringing buildings back: From abandoned properties to community assets: A guidebook for policymakers and practitioners. Rutgers University Press.

18. Nefs, M., (2006). Unused urban space: conservation or transformation? Polemics about the future of urban wastelands and abandoned buildings. City \& Time, 2(1), pp.47-58 [online] URL: http://www.ct.ceci-br.org

19. Nenno, M. K. (1996), Ending the Stalemate. University Press of America, New York. NYS.

20. Pearsall, Hamil, and Susan Lucas. (2014). "Vacant land: The new urban green?" Cities 40, Part B (0):121123. doi: http://dx.doi.org/10.1016/j.cities.2013.10.001.

21. Shlay, A.B., Whitman, G. (2006). Research for democracy: linking community organizing and research to leverage blight policy. City and Community, 5(2), pp.153-171.

22. Spelman, W., (1993). Abandoned buildings: magnets for crime? Journal of Criminal Justice, 21, pp.481495. 